J. Asiat. Soc. Bangladesh, Sci. 47(1): 67-78, June 2021 DOI: https://doi.org/10.3329/jasbs.v47i1.54187

\title{
GROWTH PERFORMANCE AND COST-BENEFIT ANALYSIS OF BRACKISHWATER FIN FISHES (MUGIL CEPHALUS AND RHINOMUGIL CORSULA) WITH PRAWN (MACROBRACHIUM ROSENBERGII) IN POLYCULTURE AT COASTAL PONDS
}

\author{
I. JAHAN, M.S. ISLAM*, M.M. SHAMSUZZAMAN, I.N. SURAVI, \\ M. AKTER AND D. SUTRADHAR \\ Department of Coastal and Marine Fisheries, \\ Sylhet Agricultural University Sylhet, Bangladesh
}

\begin{abstract}
The study was carried out to observe growth, production and profit of prawn, stripped mullet (Mugil cephalus) and corsula mullet (Rhinomugil corsula) at different stocking ratio under polyculture in the Bagerhat district for four months. The experiment was designed as a randomized block design and had three treatments based on stocking ratio with three replicates in each treatment. Juveniles of prawn (Macrobrachium rosenbergii) and fingerlings of fin fishes (stripped mullet and corsula mullet) were stocked at a stocking ratio of $3: 1: 1,4: 1: 1$ and $5: 1: 1 / \mathrm{m}^{2}$ in $\mathrm{T}_{1}, \mathrm{~T}_{2}$ and $\mathrm{T}_{3}$, respectively. Prawn and fin fishes were fed with a commercial diet and farm made formulated feed on a daily basis. Recorded water quality parameters were within suitable ranges of prawn and fish culture. Higher growth (43.0 g) of the prawn was achieved in $\mathrm{T}_{1}$ followed by $\mathrm{T}_{2}(41.0 \mathrm{~g})$ and $\mathrm{T}_{3}$ ( $38.0 \mathrm{~g}$ ), but prawn growth was not significantly different between $\mathrm{T}_{1}$ and $\mathrm{T}_{2}$. The growth and survival rate of prawn, stripped mullet and corsula mullet were lower in $\mathrm{T}_{3}$, where the stocking ratio was higher. Higher production of the prawn was obtained in $T_{2}$ (1148.0 $\mathrm{kg} / \mathrm{ha})$ than those of $\mathrm{T}_{1}(954.6 \mathrm{~kg} / \mathrm{ha})$ and $\mathrm{T}_{3}(1083.0 \mathrm{~kg} / \mathrm{ha})$. But significantly $(\mathrm{p}<0.05)$, higher production of stripped mullet was found in $\mathrm{T}_{1}(650.0 \mathrm{~kg} / \mathrm{ha})$ and $\mathrm{T}_{2}(579.5 \mathrm{~kg} / \mathrm{ha})$ than $\mathrm{T}_{3}(500.5 \mathrm{~kg} / \mathrm{ha})$. Similarly, higher production of corsula mullet was found in $\mathrm{T}_{1}$ $(850.0 \mathrm{~kg} / \mathrm{ha})$ and $\mathrm{T}_{2}(834.9 \mathrm{~kg} / \mathrm{ha})$ than $\mathrm{T}_{3}(719.8 \mathrm{~kg} / \mathrm{ha})$. However, combined production and net profit of prawn and fin fish farming were significantly $(\mathrm{p}<0.05)$ higher in $\mathrm{T}_{2}$ (2562.4 kg/ha, BDT 277,384.51/ha) followed by $\mathrm{T}_{3}(2303.3 \mathrm{~kg} / \mathrm{ha}$, BDT $229,693.95 / \mathrm{ha})$ and $\mathrm{T}_{1}(2454.6 \mathrm{~kg} / \mathrm{ha}$, BDT 179,393.31/ha). So from a production and economic point of view, polyculture of prawn and fin fish at a stocking ratio of $4: 1: 1 / \mathrm{m}^{2}$ is more profitable compared to other stocking ratios and this system may be suggested to disseminate at coastal farmers' level.
\end{abstract}

Key words: Prawn and fin fish farming, Stocking ratio, Production, Profit

*Correspondence author: <islamms2011@yahoo.com>. 


\section{Introduction}

Giant freshwater prawn (Macrobrachium rosenbergii) is one of the most desirable candidate species for freshwater aquaculture in different parts of the Indo-Pacific region (Ranjeet and Kurup 2002). It is popularly known as 'golda' in Bangladesh. Its rapid growth rate, distinctive taste, high disease resistance and high demand in both domestic and international markets have made it valuable species. Bangladesh is also considered one of the most suitable countries in the world for prawn farming due to its fertile land and environment friendly conditions. Golda farming in ponds has been increased quite rapidly in recent years in Bangladesh. The practice of integrated farming of golda with rice, fish and vegetables is spreading, particularly among small-scale farmers, providing a year round supply of crops for family subsistence supplemented by a cash crop (golda) (Fleming 2004). M. rosenbergii, being a benthophagic omnivore, is an excellent candidate for polyculture. Its culture with fish also improves the ecological balance of the pond water, preventing the formation of massive algal blooms and proper utilization of supplemented feed (Cohen and Ra'anan 1983). According to Zimmermann and New (2000), freshwater prawns are good candidates for polyculture systems. They allow fish farmers to increase productivity and profits with a small additional cost and no environmental impact. It may culture with suitable fin fish species, which can directly help to enhance production and income as a whole with an environment friendly situation.

Mullets are important culturable fish species due to their excellent growth performance, high resistance to water qualities and low mortality rates. As these three animals are having three different feeding habits (M. cephalus-bottom and column feeder, $R$. corsulasurface feeder and prawn-benthic feeder), they can be cultured economically under a polyculture system. In many countries, mullets are cultured in association with other fishes and prawn/shrimp (Uddin et al. 2006, Islam et al. 2008). Jhingran (1984) denoted some culturable brackishwater fin fishes in India, many of which apply to Bangladesh. Fin fish species like $M$. cephalus and $R$. corsula are non-carnivorous and bears high demand and market prices (Shofiquzzoha et al. 2001). These species are locally called 'bhangan' and 'khorsula'. A polyculture system may also contribute to reduce the disease risk in the pond and could offer a higher rate of production of prawn and fish than the present production from the same area with higher economic benefit.

Polyculture can increase the yield of fish and prawn/shrimp by reducing inter-specific resource competition. Another benefit of polyculture is the ability to reduce the pollution resulting from farming activity (Midlen and Redding 1998, Lutz 2003). In Bangladesh, 
despite having its great potentiality of polyculture in brackishwater, very few works have been done to date regarding this aspect. Most of the time, prawn farmers of this country could not properly harvest prawns due to miss management. So economic loss owing to suddenly prawn crop failure might be partially minimized by fin fish crop. Production and profitability of prawn and fin fish farming depend on several factors. Stocking density, feed, feeding intensity and stocking size of prawn/fish are the most imperative factors among them. Considering these facts, the present study was undertaken to assess the growth, production and economic return based on different stocking ratio of freshwater prawn, flathead grey mullet/stripped mullet (bhangan) and corsula mullet (khorsula) under a polyculture system in brackishwater ponds of the southwestern part of the country.

\section{Materials and Methods}

Study area and design: The experiment was performed in nine brackishwater earthen ponds situated at Sadar Upazila of Bagerhat district in Bangladesh from $1^{\text {st }}$ April to $30^{\text {th }}$ July 2019. The study area lies between latitude $22^{\circ} 35^{\prime} \mathrm{N}$ to $22^{\circ} 50^{\prime} \mathrm{N}$ and longitude $89^{\circ} 38^{\prime}$ E to $89^{\circ} 53^{\prime}$ E. Average area of the pond was $400 \mathrm{~m}^{2}$ and the depth of water was $0.8-1.7 \mathrm{~m}$ each. The experiment was conducted following randomized block design (RBD) with three treatments, namely $\mathrm{T}_{1}, \mathrm{~T}_{2}$ and $\mathrm{T}_{3}$, and each having three replicates. Prawn juvenile, bhangan (stripped mullet) and khorsula (corsula mullet) fingerlings were stocked at a ratio of 3:1:1, 4:1:1 and 5:1:1 nos/m in $\mathrm{T}_{1}, \mathrm{~T}_{2}$ and $\mathrm{T}_{3}$, respectively.

Earthen pond preparation and management: Before starting the experiment, ponds were treated with agricultural lime $\left(\mathrm{CaCO}_{3}\right)$ at a rate of $250 \mathrm{~kg} / \mathrm{ha}$ based on soil $\mathrm{pH}$. Ponds were then filled with tidal water gradually up to a depth of $0.9 \mathrm{~m}$ from the nearby tidal canal through a screen net. All unwanted organisms were eliminated using rotenone at a rate of $3 \mathrm{ppm}$ and then lime $\left(\mathrm{CaCO}_{3}\right)$ was applied at a rate of $125 \mathrm{~kg} / \mathrm{ha}$ for neutralizing its action. After 5 days of cleaning, ponds were fertilized with urea and TSP at a rate of 50 and $100 \mathrm{~kg} / \mathrm{ha}$, respectively. After 4-5 days of fertilization, the color of the water turned green. Fine mesh sized nylon net was used as a fence on the dikes around the ponds to prohibit the potential disease carriers fauna as a snail, crab, snake and others from outside.

Stocking of prawn and fin fishes: Hatchery produced prawn juveniles were collected from the local market. Fin fish fingerlings were collected from a private hatchery of Bagerhat. After buying, fingerlings were acclimatized for two days in a hapa. Prawn juveniles were stocked 25 days ahead of fin fish fingerlings. Before releasing the juveniles of prawn in 
ponds, polythene bags were kept in the experimental ponds for about 30 minutes and water was exchanged between bags and ponds to acclimatize with pond water temperature. After that, juveniles were released in ponds. Prawn juveniles were stocked in all ponds at a density of 3,4 and $5 \mathrm{nos} / \mathrm{m}^{2}$ but the stocking density of bhangan and khorsula was 1:1 in all treatments. Average initial weight and length of $30 \%$ of each were recorded individually before releasing them in ponds with the help of a portable digital balance (CAMRY digital electrical balance, EK 3052, Bangladesh) and a measuring scale, respectively.

Post stocking management: During the culture period, prawn were fed with commercial supplementary feed $(32.0 \%$ protein, $11.0 \%$ moisture, $4.0 \%$ crude lipid and $8.0 \%$ crude fiber-written on the feed bag) procured from the local market was applied 6 days in a week to the ponds at a rate of $10 \%$ of total prawn biomass for the first month, $6 \%$ for $2^{\text {nd }}$ month and gradually decreased up to $3 \%$ until the end of the study. Fin fishes were fed with farm made feed (40\% rice bran, $20 \%$ wheat flour, $15 \%$ corn flour, $20 \%$ fish meal and 5\% mustard oil cake) thrice a day at a rate of $10 \%$ of the total biomass for the first two months and 5-3\% of body weight at the end of the culture period. The total feed of a day was divided into three equal parts and was applied in the morning between 8.00-9.00 $\mathrm{am}$, in the noon 12.00-1.00 pm, and in the evening between 5.00-6.00 pm. Fin fish feed was used before 30-45 minutes of prawn feed applying due to proper utilization of feed and to minimize the feed competition among the cultured species. The same schedule was followed for both shrimp and fin fishes from beginning to last. Lime was applied to all ponds at monthly intervals at a rate of 50.0-75.0 kg/ha based on water depth for keeping the water quality of ponds in good condition. Dried coconut leaves, palm leaves, jute bags and bamboo's kanchi (branches of bamboo) were placed on the pond bottom to create shelter for prawn as well as other fish and to keep the water cool.

Water quality monitoring: At ten-day intervals, water quality parameters of ponds like temperature, salinity, transparency, dissolved oxygen (DO) concentration, $\mathrm{pH}$, total alkalinity and ammonia were measured between 9.00 and $10.00 \mathrm{am}$. The salinity of water was measured using a portable refractometer (ATAGO, Hand Refractometer). Surface water temperature was determined in situ using a standard centigrade thermometer. Transparency was recorded using Secchi disc. Dissolved oxygen was determined using a portable DO meter (YSI 58 digital DO meter, HANNA, Yellow Springs, Ohio 45387 USA). The $\mathrm{pH}$ of the water was recorded using a $\mathrm{pH}$ meter (HANNA, USA). Total alkalinity was measured by the titrimetric method (APHA, 2000). Ammonia nitrogen was measured using an ammonia test kit (Biotech PVT Ltd., Fishtech BD Ltd). 
Sampling, harvesting and production parameters: Fortnightly sampling of 20-25\% of stocked prawn and fin fish was done to estimate the biomass and to adjust the feeding rations and also to observe the physical conditions of the stocked species. Prawn and fin fish were sampled using a cast net. The weight and length of 40 individuals of each species were recorded for growth assessment. Weight $(\mathrm{g})$ was measured using a portable balance and length $(\mathrm{cm})$ by measuring scale. Sampling was continued until harvest.

After 120 days of culture, bamboo poles and leaves were removed, water was drained out of the ponds and all prawn and fin fish were harvested by repeated netting (cast net and surrounding net). All prawns and fish harvested from each pond were counted, measured and weighted individually to determine survival rate, growth and yield. Specific growth rate (SGR), feed conversion ratio (FCR) and survival rate (\%) were calculated following the equation as cited by Pechsiri and Yakupitiyage (2005). The equations are as follows:

Weight gain $(\mathrm{g})=$ Mean final weight $(\mathrm{g})-$ mean initial weight $(\mathrm{g})$.

Specific growth rate $(\mathrm{SGR})(\% /$ day $)=\{\mathrm{Ln}$ (final body weight $)-\mathrm{Ln}$ (initial body weight $)$ $\times 100\}$ /cultured period (days).

Feed conversion ratio $(\mathrm{FCR})=$ Feed consumed $(\mathrm{g}$ dry weight $) /$ live weight gain

( $\mathrm{g}$ wet weight) of prawn/fish.

Survival rate $(\%)=($ Number of prawn/fish harvested $\div$ total number of prawn/fish stocked) $\times 100$.

Yield of fish/prawn= No. of prawn/fish caught $\times$ (average final weight of prawn/fish- average initial weight of prawn/fish).

Economic analysis: A simple algebraic economic analysis was carried out to determine the net return and benefit-cost ratio of prawn and fin fish culture in different treatments. The following equation was used to quantify the profitability of prawn and brackishwater fin fish culture in pond systems: $N R=T R-(F C+V C+I i)$.

Where $\mathrm{NR}=$ net return, $\mathrm{TR}=$ total revenue from prawn and fin fish sales, $\mathrm{FC}=$ fixed/common costs, $\mathrm{VC}=$ variable costs and $\mathrm{Ii}=$ interest on inputs. Benefit-cost ratio (BCR) was determined as total net return/total input cost.

The prices of different kinds of inputs, prawn and fin fishes (bhangan and khorsula) correspond to the Bagerhat wholesale market prices in 2019. Prawn and fishes were sold at a rate of BDT 500.00-550.00/kg and BDT $100.00-120.00 / \mathrm{kg}$, respectively. 
Statistical analysis: Growth, production, net returns and benefit cost ratio were analyzed using one way ANOVA to compare the treatment means. If the main effect was found significant, the ANOVA was followed by DMRT (Duncan's Multiple Range Test). All ANOVA was tested at a 5\% significance level using SPSS (Statistical Package for Social Science) version 20 .

\section{Results and Discussion}

Water quality variables of culture ponds: Water quality variables of experimental ponds like temperature, transparency, dissolved oxygen, salinity, $\mathrm{pH}$, alkalinity and ammonia were measured in ten-day intervals. Water temperatures varied from 27.61 to $33.2^{\circ} \mathrm{C}$ in all treatments and was found in agreement with recorded temperature: $27.0-32.3^{\circ} \mathrm{C}$ and 28.0-35. $5^{\circ} \mathrm{C}$ by Islam et al. (2016) and Islam and Mahmud (2012), respectively. Salinity in all treatments fluctuated from 3.47 to $6.44 \mathrm{ppt}$, which resembles the findings of Islam et al. (2016), who recorded the water salinity as 1.5 to $6.5 \mathrm{ppt}$ in shrimp ponds. Water transparency was ranged from 28.78 to $36.97 \mathrm{~cm}$, which was similar to the findings of Islam et al. (2016), who recorded water transparency ranges from 28.0 to $44.0 \mathrm{~cm}$ and it was lower than the transparency $(35.0$ to $60.5 \mathrm{~cm}$ ) reported by Islam and Mahmud (2011). Dissolved oxygen (DO) recorded to range from 4.15-5.28 mg/l, which supports the findings of Islam et al. (2016), who found the DO ranges from 4.0 to $5.1 \mathrm{mg} / \mathrm{l}$ in shrimp ponds. Whereas, $\mathrm{pH}$ values varied from 6.55 to 7.36 , which is almost similar to the findings of Islam et al. (2016), who found water $\mathrm{pH}$ ranges from 7.1 to 7.7 in shrimp ponds. Total alkalinity varied from 92.33 to $101.15 \mathrm{mg} / \mathrm{l}$, which is very close to the findings of Islam et al. (2016), who found it ranges from 90.0 to $106.5 \mathrm{mg} / \mathrm{l}$ in shrimp ponds. Concentrations of ammonia nitrogen in this study ranged between 0.008 to 0.097 $\mathrm{mg} / \mathrm{l}$, which is within the acceptable level $(>0.012 \mathrm{mg} / \mathrm{l})$ of prawn/shrimp aquaculture made by Meade (1985) and Islam et al. (2016).

Growth, FCR and survival of prawn and fin fish: Almost similar sized prawn juveniles stocked in all treatment ponds, but the final weight of prawn was the highest in $\mathrm{T}_{1}$ (43.0 g) followed by $T_{2}(41.0 \mathrm{~g})$ and $T_{3}(38.0 \mathrm{~g})$, respectively. In the case of fin fishes, the highest final weight of bhangan was recorded in $\mathrm{T}_{1}(100.0 \mathrm{~g})$ than that of $\mathrm{T}_{2}(95.0 \mathrm{~g})$ and $\mathrm{T}_{3}(91.0 \mathrm{~g})$ and the highest final weight of khorsula was found in $\mathrm{T}_{1}(125.0 \mathrm{~g})$ than that of $\mathrm{T}_{2}(121.0 \mathrm{~g})$ and $\mathrm{T}_{3}(118.0 \mathrm{~g})$ (Table 1). Islam et al. (2016) recorded the mean final weight of prawn and tilapia as 58-63 and 149-199 g, respectively, in prawn and tilapia mixed culture for 150 days in farmers' shrimp ponds of Bagerhat. Islam and Mahmud (2012) recorded the final weight of prawn and tilapia as 63-73 and 163.5-168.5 g, 
respectively, for 180 days in mixed culture at different stocking density in Shrimp Research Station (SRS) pond complex, Bagerhat. Islam and Mahmud (2011) also demonstrated that final weight of prawn and tilapia as 74 to 85 and 99 to $149 \mathrm{~g}$, respectively, in brackishwater ponds at different stocking densities for 180 days in SRS

Table 1. Growth, survival rate and production (mean \pm Sd) of Macrobrachium rosenbergii, Mugil cephalus and Rhinomugil corsula in different treatments.

\begin{tabular}{|c|c|c|c|}
\hline \multirow{2}{*}{$\begin{array}{l}\text { Species and production } \\
\text { parameters }\end{array}$} & \multicolumn{3}{|c|}{ Treatments } \\
\hline & $\mathrm{T}_{1}\left(3: 1: 1 / \mathrm{m}^{2}\right)$ & $\mathrm{T}_{2}\left(4: 1: 1 / \mathrm{m}^{2}\right)$ & $\mathrm{T}_{3}\left(5: 1: 1 / \mathrm{m}^{2}\right)$ \\
\hline \multicolumn{4}{|l|}{ Macrobrachium rosenbergii } \\
\hline Average initial weight (g) & $3.0 \pm 0.13$ & $3.0 \pm 0.16$ & $3.0 \pm 0.11$ \\
\hline Average final weight (g) & $43.0^{\mathrm{a}} \pm 3.27$ & $41.0^{\mathrm{a}} \pm 3.63$ & $38.0^{\mathrm{b}} \pm 4.11$ \\
\hline Daily weight gain (g) & $0.33^{\mathrm{a}} \pm 0.03$ & $0.32^{\mathrm{a}} \pm 0.03$ & $0.29^{\mathrm{b}} \pm 0.04$ \\
\hline Survival rate $(\%)$ & $74.0^{\mathrm{a}} \pm 2.33$ & $70.0^{\mathrm{a}} \pm 2.00$ & $57.0^{\mathrm{b}} \pm 1.6$ \\
\hline Specific growth rate (\%/day) & $2.22 \pm 0.10$ & $2.18 \pm 0.12$ & $2.12 \pm 0.12$ \\
\hline Production (kg/ha) & $954.6^{c} \pm 30.10$ & $1148.0^{\mathrm{a}} \pm 32.8$ & $1083.0^{\mathrm{b}} \pm 30.4$ \\
\hline \multicolumn{4}{|l|}{ Mugil cephalus } \\
\hline Average initial weight (g) & $3.5 \pm 0.19$ & $3.5 \pm 0.23$ & $3.5 \pm 0.20$ \\
\hline Average final weight (g) & $100.0^{\mathrm{a}} \pm 3.16$ & $95.0^{\mathrm{b}} \pm 3.08$ & $91.0^{c} \pm 2.89$ \\
\hline Daily weight gain (g) & $0.81^{\mathrm{a}} \pm 0.03$ & $0.76^{\mathrm{b}} \pm 0.03$ & $0.73^{c} \pm 0.03$ \\
\hline Survival rate $(\%)$ & $65.0^{\mathrm{a}} \pm 2.0$ & $61.0^{\mathrm{b}} \pm 1.75$ & $55.0^{\mathrm{c}} \pm 1.5$ \\
\hline Specific growth rate (\%/day) & $2.79 \pm 0.08$ & $2.75 \pm 0.08$ & $2.72 \pm 0.08$ \\
\hline Production (kg/ha) & $650.0^{\mathrm{a}} \pm 20.0$ & $579.5^{\mathrm{b}} \pm 16.63$ & $500.5^{c} \pm 13.65$ \\
\hline \multicolumn{4}{|l|}{ Rhinomugil corsula } \\
\hline Average initial weight (g) & $4.0 \pm 0.27$ & $4.0 \pm 0.25$ & $4.0 \pm 0.22$ \\
\hline Average final weight (g) & $125.0^{\mathrm{a}} \pm 4.25$ & $121.0^{\mathrm{b}} \pm 3.92$ & $118.0^{c} \pm 3.67$ \\
\hline Daily weight gain (g) & $1.01 \pm 0.02$ & $0.98 \pm 0.04$ & $0.95 \pm 0.03$ \\
\hline Survival rate $(\%)$ & $68.0^{\mathrm{a}} \pm 3.0$ & $69.0^{\mathrm{a}} \pm 1.75$ & $61.0^{\mathrm{b}} \pm 2.0$ \\
\hline Specific growth rate (\%/day) & $2.87 \pm 0.08$ & $2.84 \pm 0.08$ & $2.82 \pm 0.07$ \\
\hline Production (kg/ha) & $850.0^{\mathrm{a}} \pm 37.5$ & $834.9 \mathrm{~b} \pm 21.2$ & $719.8^{c} \pm 23.6$ \\
\hline Combined production $(\mathrm{kg} / \mathrm{ha})$ & $2454.6^{\mathrm{b}} \pm 54.7$ & $2562.4^{\mathrm{a}} \pm 82.6$ & $2303.3^{\mathrm{c}} \pm 97.4$ \\
\hline
\end{tabular}

Mean value in the same row with same superscript letters are not significantly differently $(\mathrm{p}>0.05)$. 
pond complex, which are slightly higher than the findings of the present study. Shofiquzzoha and Alam (2008) mentioned that the final weight of shrimp and silver barb was 23.77 and $69.75 \mathrm{~g}$, respectively, in concurrent culture for 120 days at Brackishwater Station (BS) pond complex, Khulna, which is lower than the present findings. They also recorded the final weight of shrimp and tilapia as 24.93 and $161.83 \mathrm{~g}$, respectively, for 120 days in the same pond complex, which is also lower than the present findings except for tilapia.

Daily weight gain recorded for prawn, bhangan and khorsula as $0.29-0.33,0.73-0.81$ and $0.95-1.01 \mathrm{~g}$, respectively, for 120 days (Table 1). It is mentioned here that the daily weight gain of prawns was not significantly different between $\mathrm{T}_{1}$ and $\mathrm{T}_{2}$. Islam et al. (2016) calculated the daily weight of prawn and tilapia as $0.39-0.42$ and $0.99-1.33 \mathrm{~g}$, respectively, in shrimp ponds. Islam and Mahmud (2012) reported the daily weight of prawn and tilapia as $0.35-0.41$ and $0.91-0.94 \mathrm{~g}$, respectively, at different stockings. Islam and Mahmud (2011) also demonstrated the daily weight of prawn and tilapia as $0.41-0.47$ and $0.55-0.83 \mathrm{~g}$, respectively, in brackishwater ponds. Shofiquzzoha and Alam (2008) stated that the daily weight of shrimp and silver carb in contemporary culture was 0.20 and $0.55 \mathrm{~g}$, respectively, for 120 days, which is lower than the present findings. They also recorded the daily the weight of shrimp and tilapia as 0.21 and $1.34 \mathrm{~g}$, respectively, for 120 days in the same pond complex, corresponding with the present findings.

The specific growth rate (SGR) of prawn (2.12-2.22) was not significantly different among treatments. On the other side, the highest SGR of bhangan was found in $T_{1}$ (2.79) and lowest in $\mathrm{T}_{3}$ (2.72). SGR of khorsula was higher in $\mathrm{T}_{1}$ (2.87) and lower in $\mathrm{T}_{3}(2.82)$. Islam et al. (2016) recorded SGR of prawn and tilapia as $1.52-1.65$ and $3.98-4.13 \%$, respectively, in shrimp ponds. SGR of prawn and tilapia ranged between 1.71-1.80 and 3.13-3.15\%, respectively reported by Islam and Mahmud (2012). Thus, The findings of prawns of the above mentioned studies are lower, but tilapia findings are higher than this study. However, Shofiquzzoha and Alam (2008) observed SGR of shrimp and tilapia as 6.94 and $4.26 \%$, respectively, for 120 days, higher than the present findings.

Feed conversion ratio (FCR) of prawn and fin fishes was significantly lower in $\mathrm{T}_{1}$ (2.56) than that of $\mathrm{T}_{2}$ (2.90) and $\mathrm{T}_{3}$ (3.20). These findings coincide with Islam et al. (2016), who recorded FCR of prawn and tilapia as 2.70-3.60. Chanratchakool et al. (1995) stated that FCR varies with the stocking density, quality of feed and the size at which the shrimps were harvested and also depended on the production cycle and between populations. Hasan (2001) reported FCR increased/decreased with the quality of supplemented feed 
and with the mean weight of prawn/shrimp/fish as they grew. In this study, the lowest FCR was recorded in $T_{1}$, which seems to be due to efficient utilization of maximum ratio by prawn and fin fishes.

The survival rate of the prawn was significantly $(\mathrm{p}<0.05)$ higher in both $\mathrm{T}_{1}$ $(74.00 \pm 2.33 \%)$ and $\mathrm{T}_{2}(70.00 \pm 2.00 \%)$ than $\mathrm{T}_{3}(57.00 \pm 1.60 \%)$, but there was no significant difference between $\mathrm{T}_{1}$ and $\mathrm{T}_{2}$. On the contrary, survival of bhangan was highest in $\mathrm{T}_{1}(65.0 \pm 2.00 \%)$ and was lowest in $\mathrm{T}_{3}(55.00 \pm 1.50 \%)$. Besides, Thus, a survival of khorsula was highest in $\mathrm{T}_{2}(69.0 \pm 1.75 \%)$ and lowest in $\mathrm{T}_{3}(61.00 \pm 2.00 \%)$. Significant difference in survival of bhangan and khorsula under three treatments was observed (Table 1). Similar, survival of prawn and tilapia as 66-72 and 56.2-65.5\%, respectively for 150 days was demonstrated by Islam et al. (2016), and Islam and Mahmud (2012) recorded survival of prawn and tilapia as 62-70 and 68-71.5\%, respectively for 180 days. Islam and Mahmud (2011) obtained the survival of these species as $58-65$ and $66-73 \%$, respectively. It was observed that growth rate and survival of prawn decreases with the increase of stocking density of fin fishes. Survival rate and growth were also associated with water depth and space in ponds. The present study observed significantly lower SGR and survival of prawn in $T_{3}$, it could be due to intra and inter-specific competition among the animals stocked. Garcia-Perez et al. (2000) stated that there are many factors that affect the survival of prawn/shrimp as environmental stress, water level, the required amount of feed, stocking ratio, cannibalism, bird predation, predator fish, etc. Cannibalism during moulting period is a common phenomenon and may be responsible for monthly mortality of $4 \%$ (AQUACOP, 1990).

Production of prawn and fin fishes (bhangan and khorsula): Daily weight gain and survival rate of prawn under $T_{1}$ and $T_{2}$ was not significantly different. But the number of prawn counted more in $T_{2}$ at harvest than $T_{1}$ due to higher stocking density in $T_{2}$. So prawn production $\left(1148.0 \mathrm{~kg} / \mathrm{ha}\right.$ ) obtained highest in $\mathrm{T}_{2}$, which was significantly different $(\mathrm{p}<0.05)$ than $\mathrm{T}_{1}\left(954.6 \mathrm{~kg} / \mathrm{ha}\right.$ ) but not significantly different from $\mathrm{T}_{3}(1083.0 \mathrm{~kg} / \mathrm{ha})$. It also enhanced the combined production and economic profit of the polyculture system of prawn and fin fishes. As opposed to, higher production $(650.0 \mathrm{~kg} / \mathrm{ha})$ of bhangan was found in $T_{1}$, which was significantly different $(\mathrm{p}<0.05)$ than that of $\mathrm{T}_{3}(500.5 \mathrm{~kg} / \mathrm{ha})$ but not significantly different from $\mathrm{T}_{2}(579.5 \mathrm{~kg} / \mathrm{ha})$. Higher production $(850.0 \mathrm{~kg} / \mathrm{ha})$ of khorsula was obtained in $\mathrm{T}_{1}$, which was significantly different $(\mathrm{p}<0.05)$ than that of $\mathrm{T}_{3}$ (719.8 kg/ha), but there was no significant difference between $\mathrm{T}_{1}(850 \mathrm{~kg} / \mathrm{ha})$ and $\mathrm{T}_{2}$ $(834.9 \mathrm{~kg} / \mathrm{ha})$. The combined production of prawn and fin fishes was $2454.6,2562.4$ and $2303.3 \mathrm{~kg} / \mathrm{ha}$ in $\mathrm{T}_{1}, \mathrm{~T}_{2}$ and $\mathrm{T}_{3}$, respectively. Significantly $(\mathrm{p}<0.05)$ higher combined 
production (2562.4 kg/ha) was achieved in $\mathrm{T}_{2}$ followed by $\mathrm{T}_{1}(2454.6 \mathrm{~kg} / \mathrm{ha})$ and $\mathrm{T}_{3}$ (2303.3 kg/ha) (Table 1). Observed production was almost similar with the findings of Islam et al. (2016) and Islam and Mahmud (2012), who recorded combined production of prawn and tilapia as $2491.80-2510.60 \mathrm{~kg} / \mathrm{ha} / 150$ days and $2191.39-2441.47 \mathrm{~kg} / \mathrm{ha} / 150-$ 180 days, respectively. But the findings of the present study are higher than the findings (1105.0-2133.4 kg/ha/180 days) of Islam and Mahmud (2011). In contrast, the production of shrimp reported by Islam and Mahmud (2010) and Shofiquzzoha and Alam (2008) was 416.9-641.7 kg/ha and $402.73 \mathrm{~kg} / \mathrm{ha}$, respectively, which are lower than the production found in the present study. Total production of the present study was higher than Islam and Mahmud (2010) due to might be associated with thrice species stocked, higher protein percentage of supplied feed, better size of prawn and fin fish juvenile/fry as well as good management of water quality. The combined yield of prawn and tilapia reported by Asaduzzaman et al. (2009) was $1,763.0 \mathrm{~kg} / \mathrm{ha} / 120$ days, which is lower than the present findings. The highest combined production obtained by Uddin et al. (2006) in ponds stocked with $75 \%$ tilapia and $25 \%$ prawn was $1,691 \mathrm{~kg} / \mathrm{ha}$, which is also less than the present study.

Profit of prawn and fin fish (bhangan and khorsula) farming: Total net profit of prawn and fin fish (bhangan and khorsula) farming was significantly higher in $\mathrm{T}_{2}$ (BDT 2,77,384.51/ha) followed by $\mathrm{T}_{3}$ (BDT 2,29,693.95/ha) and $\mathrm{T}_{1}$ (BDT 1,79,393.31/ha). The benefit-cost ratio (BCR) was also higher in $\mathrm{T}_{2}(1.57)$ compared to $\mathrm{T}_{3}(1.48)$ and $\mathrm{T}_{1}$ (1.41), respectively (Table 2). The observed profit was slightly higher than the findings of Islam et al. (2016), who achieved the profit from prawn and tilapia farming as BDT 147,819.00-238,923.00/ha in brackishwater ponds. Islam and Mahmud (2011) recorded

Table 2. Cost-Benefit analysis of prawn (Macrobrachium rosenbergii), bhangan (Mugil cephalus) and khorsula (Rhinomugil corsula) production in different treatments.

\begin{tabular}{lccc}
\hline Particulars & \multicolumn{3}{c}{ Treatments } \\
\cline { 2 - 4 } & $\mathrm{T}_{1}\left(3: 1: 1 / \mathrm{m}^{2}\right)$ & $\mathrm{T}_{2}\left(4: 1: 1 / \mathrm{m}^{2}\right)$ & $\mathrm{T}_{3}\left(5: 1: 1 / \mathrm{m}^{2}\right)$ \\
\hline Total gross return (BDT/ha) & $6,16,938.00 \pm 2837.45$ & $7,64,024.00 \pm 3418.62$ & $7,08,223.00 \pm 3592.48$ \\
Total cost (BDT/ha) & $4,37,544.68 \pm 3591.30$ & $4,86,639.49 \pm 3618.85$ & $4,78,529.05 \pm 4116.87$ \\
Net profit (BDT/ha) & $1,79,393.31^{\mathrm{c}} \pm 3729.18$ & $2,77,384.51^{\mathrm{a}} \pm 6513.52$ & $2,29,693.95^{\mathrm{b}} \pm 3642.30$ \\
Benefit cost ratio (BCR) & $1.41^{\mathrm{c}}: 1$ & $1.57^{\mathrm{a}}: 1$ & $1.48^{\mathrm{b}}: 1$ \\
\hline
\end{tabular}

Mean values in the same row with different superscript letters indicate significantly different $(\mathrm{p}<0.05)$.

the profit of prawn and tilapia culture ranges from BDT 137,021.00 to 236,797.00/ha, which is also lower than the present study's findings. Islam and Mahmud (2010) found 
the net profit of shrimp farming as BDT 45,086.33-181,182.35, which is much lower than the present findings. Results of the study indicated that the stocking ratio of fin fish affected the economic return positively. There was no adverse change in water quality due to the different densities of fin fishes. Further, the inclusion of fin fish did not hamper the growth and production of prawns. Presently, the polyculture system has been getting more popular over monoculture due to its contribution to boosting total fish production worldwide. From the viewpoint of growth, production and economic return, the farming of prawn, bhangan and khorsula at a stocking ratio of $4: 1: 1 / \mathrm{m}^{2}$ is a profitable aquaculture system in coastal areas. So based on production and economic performance, it may conclude from the study results that the polyculture of prawn and fin fishes (bhangan and khorsula) at a ratio of $4: 1: 1 / \mathrm{m}^{2}$ could be advised to adopt at farmers' level for getting high production and significant economic profit.

\section{References}

APHA (American Public Health Association). 2000. Standard methods for the examination of water and wastewater (18th edition). American Public Health Association, 1015 Eighteenth Street, N. W. Washington, D. C.

AQUACOP. 1990. Freshwater prawns. In: Norton M, (Ed.). Aquaculture. Bookcraft Limited, London, UK, pp. 501-528.

Asaduzzaman, M., M.A. Wahab, M.C.J. Verdegem, S. Benerjee, T. Akter, M.M. Hasan and M.E. Azim. 2009. Effects of addition of tilapia Oreochromis niloticus and substrates for periphyton developments on pond ecology and production in $\mathrm{C} / \mathrm{N}-$ controlled freshwater prawn Macrobrachium rosenbergii farming systems. Aquaculture 287: 371-380.

Chanratchakool, P.J.F., S. Turnbul, S. Fung and C.L. Wan. 1995. Health Management in shrimp ponds" $2^{\text {nd }}$ edition. Published by Aquatic Animal Health Research Institute. Dept. of Fisheries. Kasetsart University Campus, Jatujak, Bankok 10900, Thailand. pp. 111.

Cohen, D. and Z. Ra'anan. 1983. The production of the freshwater prawn Macrobrachium rosenbergii in Israel: III. Density effect of all-male Tilapia hybrids on prawn yield characters in polyculture. Aquaculture 35: 57-71.

Fleming, C. 2004. Challenges facing the shrimp industry in Bangladesh. American International School, Dhaka, Senior Project 2004, pp 24.

Garcia-Perez, A., D.E. Alston and R. Cortees Maldonado. 2000. Growth, survival, yield and size distributions of freshwater prawn Macrobrachium rosenbergii and tilapia Oreochromis niloticus in polyculture and monoculture systems in Puerto Rico. J. World Aquaculture Society 31(3): 446-451.

Hasan, M.R. 2001. Nutrition and feeding for sustainable aquaculture development in the third millennium. In: Subasinghe, R.P. Bueno, P. Phillips, M.J. Hough, C. McGladdery, S.E. and Arthur, J.R. (eds.), Aquaculture in the Third Millennium. Technical Proceedings of the Conference on Aquaculture in the Third Millennium held on 20-25 February 2000, NACA, Bangkok, Thailand and FAO, Rome. pp. 193-219. 
Islam, M.S., Y. Mahmud and N. Begum. 2016. Inclusion of monosex tilapia (Oreochromis niloticus) with freshwater prawn (Macrobrachium rosenbergii) in polyculture systems in the ponds of coastal region: impact of stocking density of tilapia on production and profitability. American Journal of Experimental Agriculture 13(3): 1-9.

Islam, M.S. and Y. Mahmud. 2012. Impact of stocking density of freshwater prawn (Macrobrachium rosenbergii) and monosex tilapia (Oreochromis niloticus) on production and economic return under polyculture systems in brackishwater ponds. Eco-friendly Agril.J. 5(12): 257-263.

Islam, M.S. and Y. Mahmud. 2011. Performance of fresh water prawn with tilapia and rui in brakishwater pond. SAARC J. Agri. 9(1): 107-121.

Islam, M.S. and Y. Mahmud. 2010. Impact of different feeds on production and economic return of tiger shrimp (Penaeus monodon) in coastal aquaculture farm. Bangladesh Journal of Agriculture 35(1): 119-126.

Islam, M.S., K.A. Huq and M.A. Rahman. 2008. Polyculture of Thai pangus (Pangasius hypophthalmus, Sauvage 1878) with carps and prawn: A new approach in polyculture technology regarding growth performance and economic return. Aquaculture Research 39(15): 1620-1627.

Jhingran, A.G. 1984. The Fish Genetic Resources of India: Bureau of Fish Genetic Resources, Allahabad and Maya Press Pvt. Ltd, Allahabad, 82.

Lutz, C.G. 2003. Polyculture: principles, practices, problems and promise. Aquaculture Magazine 29: 34-39.

Meade, J.W. 1985. Allowable Ammonia for Fish Culture. Prog. Fish culture 47: 135-145.

Midlen, A. and T. Redding. 1998. Environmental management for aquaculture. Netherlands, Kluwer Academic Publishers. pp. 223.

Pechsiri, J. and A. Yakupitiyage. 2005. A comparative study of growth and feed utilization efficiency of sex-reversed dipliod and triploid Nile tilapia (Oreochromis niloticus L.). Aquaculture Research 36: 45-51.

Ranjeet, K. and B.M. Kurup. 2002. Heterogeneous individual growth of Macrobrachium rosenbergii male morphotypes. Naga 25(2): 13-18.

Shofiquzzoha, A.F.M. and M.J. Alam. 2008. Culture feasibility of silver barb (Barbodes gonionotus Bleeker) and GIFT with shrimp (Penaeus monodon Feb.) in brackishwater pond. Bangladesh Journal of Fisheries Research 12(1): 69-74.

Shofiquzzoha, A.F.M., M.L. Islam and S.U. Ahmed. 2001. Optimization of stocking rates of shrimp (P. monodon) with brackishwater finfish in a polyculture system. Online Journal of Biological Sciences 1(8): 694-697.

Uddin, M.S., M.E. Azim, M.A. Wahab and M.C.J. Verdegem. 2006. The potential of mixed culture of genetically improved farmed tilapia (Oreochromis niloticus) and freshwater giant prawn (Macrobrachium rosenbergii) in periphyton based systems. Aquaculture Research 37: 241247.

Zimmermann, S. and M.B. New. 2000. Grow-out systems polyculture and integrated culture. In: MB New, WC Valenti (Editors), Freshwater Prawn Culture, Blackwell Science, Oxford, UK. pp. 187-202.

(Revised copy received on 17.05.2021) 